\title{
5. 内耳道への耳科学的手術アプローチ
}

\author{
○小池吉郎 · 水越鉄理 $\cdot$ 大野吉昭 ·加藤 功 - 青柳 優 $\cdot$ 大竹欣也（新潟大）
}

内耳道への耳科的アプローチ法は, 経中頭蓋召法と経 迷路法に大別される，前者は，外倁性顔面神経麻㾇で， 障害部位が，顔神管水平部より内耳孔までと推定された 時, とられるアプローチ法であり, 経乳突部法を併用し 全顔面神経減圧術を行なう時屡々, 応用される. 又, メ ニエール病で, 聴力を保存して, 前庭神経のみを切断し, メマイ発作を止めるよらな場合にも応用される，後者の 経迷路法は，聴神経腫湟で，腫浧の大きさが， $2-2.5 \mathrm{~cm}$ 以下で内耳道に限局しておると診断された時, 腷外科で 行なわれる経後頭蓋窝法に代つて，近年，耳鼻科でも行 なわれるようになつた。われわれは側頭骨横骨折により 生じた顔面神経麻哽に対し，経中頭蓋召法と経乳突法を 併用し，全顔面神経減圧術を行なつた症例と，内耳道に 限局せる第 8 神経腫瘍に対し, 経迷路法で摘出した症例 を映画にて撮影した．併せて内耳道のアプローチ法の手
技について，若干の解説を加えた，特に，経中頭蓋窩法 で, 内耳道に入る目標には, 浅大錐体神経の露出端より ドラールザックに入る方法と, 上半規管の膨隆部より $60^{\circ}$ の角度で下降してドラールザックに達する方法と二種類 あるが，この両者のアプローチ法の長欠点を述べた。

質問 戸塚元吉 (虎の門). 前方に進展した腫瘍にお いて腫瘍全剔の方法は如何，また，開頭することを予定 しているのか，また術後の䯣液屡の予防のため，術創の 閉鎖に何か特別の配慮があるか

応答 小池吉郎

(新潟大)，第V脳神経症状があるとやはり combined approach でなければならない場合がある，そのときに は,まず trans labyrinthine approach で labyrinthectomy を行なう. Liquorrhoe については, temporal Fascia と muscle のみでは不充分で， biobond を使用してからあ まりない。

\section{6. 萎縮 性鼻炎 （鼻腔側壁下半部自家骨組織充填法）}

\section{高橋 良○吉田 健・蒌池泰久（慈大）}

萎縮性鼻炎の手術的療法については，Lautenschläger 法以来幾多の方法が報告されているが，末だ充分満足の いく方法は見られないよ5である。それらの方法は概ね 鼻腔の狭小化により鼻内気流に抵抗を与えて鼻粘膜の乾 燥化を防ぎ，変性した粘膜の正常化を計るものである が，鼻腔側壁移動法や鼻腔側壁内充填法では鼻涙管が目 的達成の障害となり，悬涙管の通過障害や閉塞をきたさ ないように処置するため，充分な鼻腔の狭小化を計れな かつた，われは積極的に鼻涙管周囲の骨を除去乙其涙管 を可動性にすることにより何の障害もなく舅腔の狭小化 に成功した.

基の手術手技は Caldwell-Luc の方法に淮じて梨状孔 縁を露出これを拡大して鼻腔側壁粘膜の剝離を進める
と直ちに鼻滬管前部の骨に達する，この部を直視下にノ ミで除去し鼻涙管を露出，可動性を得ることにより下甲 介および下鼻道粘膜を充分に正中側に移動可能となる.

こうしてできた腔に腸骨骨娟片を挿入充塓する.

この手術法は容易で，充分な鼻腔の狭小化が可能であ り，又既往に鼻副鼻腔の手術を行なつた症例においても 何の障害もなく施行可能である.

質問 熊沢忠躬 (関西医大). (1)前の手術はどのよう なものだつたか.（2)骨以外のものではどうか。（3)粘膜切 開を中央にし，雨側1度にできないか。応答 吉田 健 (慈大)，(1)上顎洞根治手術を施行している. (2)感染 の危険の多い部位なので，自家骨骨髄を使用した。(3)同 時に両側鼻腔の手術施行も可能である. 